\title{
CELESTINESCA
}

https://doi.org/10.7203/Celestinesca.11.19651

\section{A NOTE ON CHRISTINE DE PIZAN AND PETRARCH}

\author{
Angus J. Kennedy \\ University of Glasgow
}

\begin{abstract}
David Hook's article in Celestinesca 6, i (May 1982), pp. 1-7, on three variations on a Petrarchan theme, devotes a useful and substantial note (no. 5) to an examination of Christine de Pizan's possible knowledge of Petrarch, indicating that 'Christine does not, however, appear to mention Petrarch by name.' Christine does mention and quote Petrarch explicitly in the Livre de la cité des dames: ${ }^{1}$ "Et de ce bien dit voir Petrac, qui dist: 'O fol homme: tu desires avoir enffans, mais tu ne puez avoir nulz sy mortelz annemis: car, se tu es povre, ils seront tanés de toy et desireront ta mort pour en estre deschargiez; et se tu es riche, ilz ne la desireront pas moins: pour avoir le tien'." Curnow ${ }^{2}$ has not been able to trace these specific. words in the most likely source, Petrarch's De remediis utriusque Fortunae, translated (as Hook mentions) for Charles $V$ by Jean Daudin, but points to the fact that the ideas are similar; to those found in many passages in this particular work.
\end{abstract}

\section{NOTES}

1ed. M. C. Curnow, Ph.D. thesis, Vanderbilt Univ., 2 vols, 1975, pp. 306-7. See also The Book of the City of Ladies, trans. by E. J. Richards, New York: Persea Books, 1982, II.7.1, and La Cité des Dames, texte traduit et présenté par T. Moreau et E. Hicks, Paris: Stock, 1986, p. 139.

${ }^{2}$ Curnow, p. 1082.

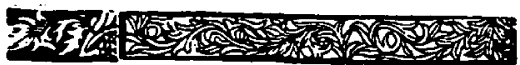

